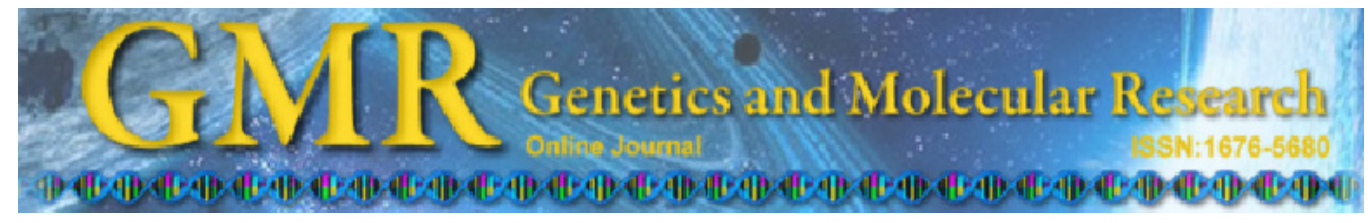

\title{
Polymorphisms of the cocaine-amphetamine- regulated transcript (CART) gene and their association with reproductive traits in Chinese goats
}

\author{
P.Q. Wang1, L.M. Deng' ${ }^{1}$, B.Y. Zhang ${ }^{1}$, M.X. Chu ${ }^{2}$ and J.Z. Hou $^{3}$ \\ ${ }^{1}$ College of Bioengineering, Chongqing University, Chongqing, P.R. China \\ ${ }^{2}$ Key Laboratory of Farm Animal Genetic Resources and \\ Utilization of Ministry of Agriculture, Institute of Animal Science, \\ Chinese Academy of Agricultural Sciences, Beijing, P.R. China \\ ${ }^{3}$ School of Chemistry and Chemical Engineering, \\ Southwest Petroleum University, Chengdu, P.R. China \\ Corresponding author: P.Q. Wang \\ E-mail: wang_pq@21cn.com
}

Genet. Mol. Res. 10 (2): 731-738 (2011)

Received October 4, 2010

Accepted November 10, 2010

Published April 26, 2011

DOI 10.4238/vol10-2gmr1091

\begin{abstract}
Polymorphisms of the CART gene were investigated by PCR-single-strand conformation polymorphism analysis in 540 samples from 10 goat breeds. Ten novel single-nucleotide polymorphisms as well as three microsatellites were detected; a mutation, $77 \mathrm{~T} \rightarrow \mathrm{C}$, led to an amino acid change (Leu $\rightarrow$ Ser). Associations between polymorphic loci and reproductive traits were analyzed in Chuandong White, Guizhou White and Gulin Ma breeds. Mutation at position 524 had no significant effect on litter size in these three goat breeds. The polymorphism $539 \mathrm{C} \rightarrow \mathrm{A}$ differed significantly among the three breeds $(\mathrm{P}<0.05)$; $\mathrm{C}_{7} \mathrm{~T}_{8} / \mathrm{C}_{9} \mathrm{~T}_{8}$ at 939 was associated with larger litter size $(\mathrm{P}<0.05)$ than genotypes $\mathrm{C}_{7} \mathrm{~T}_{8} / \mathrm{C}_{7} \mathrm{~T}_{8}$ and $\mathrm{C}_{7} \mathrm{~T}_{8} / \mathrm{C}_{8} \mathrm{~T}_{8}$. No significant association of birth weight was found with gene variation $(524 \mathrm{C} \rightarrow \mathrm{T}, 539 \mathrm{C} \rightarrow \mathrm{A}$ and 939
\end{abstract}


$\mathrm{C}_{\mathrm{n}} \mathrm{T}_{\mathrm{n}}$ ). These findings could be valuable for marker-assisted selection for goat breeding.

Key words: CART gene; SNPs; Microsatellites; Reproduction traits; Goats

\section{INTRODUCTION}

Cocaine- amphetamine-regulated transcript (CART), identified by Douglass et al. (1995), was implicated in a wide range of behaviors, including the regulation of food intake, energy homeostasis, and reproduction (Smith et al., 2004; Boone et al., 2008; Lima et al., 2008; Derks et al., 2009). More precisely, CART peptides, which are distributed in the arcuate nucleus, lateral hypothalamus, paraventricular nucleus (PVN), and nucleus accumbens (Koylu et al., 1998; Rogge et al., 2008), can be positively regulated by leptin, then inhibit food intake and stimulate the pituitary-gonadal axis together with $\alpha$-melanocyte-stimulating hormone ( $\alpha$-MSH) (Kalra et al., 1999; Van Vugt et al., 2006). Since leptin stimulation of in vitro GnRH release can be blocked by the addition of antibody to CART protein, leptin's action on the reproductive neuroendocrine axis may be mediated by CART (Van Vugt et al., 2006). Moreover, CART peptides are expressed in arcuate neurons that project to the PVN and regulate the release of thyrotropin-releasing hormone (TRH) (Fekete et al., 2000; Fekete and Lechan, 2006). By regulating TRH release, CART peptides can influence the pituitary-thyroid axis, with a resultant effect on energy expenditure.

The effects of mutation on the CART gene have also been investigated in several species. In humans, the missense mutation Leu 34 Phe may lead to obesity (Yanik et al., 2006). Reports in cattle showed that some single nucleotide polymorphisms (SNPs) $(-636 \mathrm{~T} \rightarrow \mathrm{C},-521 \mathrm{~T} \rightarrow \mathrm{C},-1431 \mathrm{~T} \rightarrow \mathrm{C},-398 \mathrm{~T} \rightarrow \mathrm{C}$, and $234 \mathrm{~A} \rightarrow \mathrm{G})$ were associated with growth traits (Zhang et al., 2008). Findings in pigs demonstrated that swine with $(\mathrm{CA})_{2}(\mathrm{CG})_{1}(\mathrm{CA})_{9}$ or $(\mathrm{CA})_{2}(\mathrm{CG})_{3}(\mathrm{CA})_{11}$ had significant effects on meat content carcass $(\mathrm{P}<0.05)$ in both Polish Large White and Polish Landrace breeds (Stachowiak et al., 2009). However, few studies related to gene variation of the CART gene in goats and its association with reproduction traits have been reported. Considering the economic value of farm animal genetic resources, the present study aimed to detect SNPs in this gene from 10 goat breeds, including 9 dominant and 1 import breeds; meanwhile, associations with litter size and birth weight were also analyzed in Chuandong white, Guizhou white and Gulin ma breeds.

\section{MATERIAL AND METHODS}

\section{Animals and DNA isolation}

Venous jugular blood samples $(10 \mathrm{~mL}$ per doe $)$ were collected from 10 goat breeds: Chuandong white $(\mathrm{N}=55)$, Jintang black $(\mathrm{N}=41)$, Banjiao $(\mathrm{N}=45)$, Dazu black $(\mathrm{N}=51)$, Guizhou white $(\mathrm{N}=99)$, Nanjiang huang $(\mathrm{N}=74)$, Chengdu ma $(\mathrm{N}=40)$, Gulin ma $(\mathrm{N}=58)$, Matou $(\mathrm{N}=49)$, and Boer $(\mathrm{N}=31)$, using acid citrate dextrose as an anticoagulant. These doe were chosen at random. Genomic DNA was extracted from whole blood by the phenolchloroform method and dissolved in TE buffer (10 mM Tris-HCl, pH 8.0), 1 mM EDTA, pH 8.0 , and kept at $-20^{\circ} \mathrm{C}$. 


\section{Primer design and polymerase chain reaction}

All primer pairs (data available on request), designed based on cattle sequence (GenBank No. AY603972.1) in NCBI Genbank databases, were used to detect SNPs in different coding regions of the whole CART gene through the analysis based on the combination of polymerase chain reaction and single-strand conformation polymorphisms (PCR-SSCP). PCRs were carried out in a $20-\mu \mathrm{L}$ reaction mixture containing approximately $10 \mathrm{pM}$ of each primer, $2.5 \mathrm{mM} \mathrm{MgCl}, 0.2 \mathrm{mM}$ dNTP, $100 \mathrm{ng}$ caprine genomic DNA and $2.5 \mathrm{U}$ Taq DNA polymerase (Promega, Madison, WI, USA). The cycling protocol was $5 \mathrm{~min}$ at $90^{\circ} \mathrm{C}$, followed by 35 cycles of $95^{\circ} \mathrm{C}$ for $30 \mathrm{~s}$, annealing at various temperatures ranging from $58^{\circ}$ to $63^{\circ} \mathrm{C}$, according to the primer set, for $30 \mathrm{~s}, 72^{\circ} \mathrm{C}$ for $30 \mathrm{~s}$, with a final cycle at $72^{\circ} \mathrm{C}$ for $10 \mathrm{~min}$ in a Mastercycler 5333 (Eppendorf AG, Hamburg, Germany).

\section{Single-stranded conformation polymorphism}

A volume of $3 \mu \mathrm{L}$ PCR products mixed with $7 \mu \mathrm{L}$ of a solution containing $98 \%$ formamide, $0.025 \%$ bromophenol blue, $0.025 \%$ xylene cyanol, $10 \mathrm{mM}$ EDTA, $\mathrm{pH} 8.0$, and $10 \%$ glycerol was transferred to an Eppendorf tube, denatured at $98^{\circ} \mathrm{C}$ for $10 \mathrm{~min}$, and then cooled down at $-20^{\circ} \mathrm{C}$ for $10 \mathrm{~min}$. Next, they were separated by electrophoresis on a $12 \%$ neutral polyacrylamide gel (acrylamide:bisacrylamide, 39:1) at $9-15 \mathrm{~V} / \mathrm{cm}$ for $14-16 \mathrm{~h}$ at $4^{\circ} \mathrm{C}$ and then stained with silver nitrate (silver staining). Finally, patterns and analysis were carried out using AlphaImager ${ }^{\text {TM }} 2200$ \& 1220 Documentation \& Analysis Systems (Alpha Innotech Corporation, San Leandro, CA, USA).

\section{Cloning and sequencing}

PCR products of different homozygous genotypes were separated on $1.0 \%$ agarose gels and recovered using the Geneclean II kit (Promega). According to manufacturer instructions, each DNA fragment, which was ligated into the pGEM-T Easy vector (Promega) in a $10-\mu \mathrm{L}$ volume consisting of $1 \mu \mathrm{L}$ PCR product, $1 \mu \mathrm{L}$ pGEM-T Easy vector $(50 \mathrm{ng} / \mu \mathrm{L}), 1 \mu \mathrm{L}$ T 4 ligase $(3 \mathrm{U} / \mu \mathrm{L}), 5 \mu \mathrm{L} 2 \mathrm{X}$ ligation buffer, and $2 \mu \mathrm{L} \mathrm{ddH}_{2} \mathrm{O}$, was transformed into Escherichia coli DH5 $\alpha$ competent cells. Two clones of each homozygous genotype identified by restriction enzyme digestion were selected and sequenced three times from both directions using an automatic ABI 377 sequencer (Perkin Elmer Applied Biosystems, Foster City, CA, USA) by Beijing Dingguo Biotechnology Ltd. Co. (Beijing, China).

\section{Statistical analysis}

The following statistical model was fitted to compare the litter size or birth weight in Guizhou white, Gulin ma and Chuandong white goats among different genotypes by least squares analysis of variance.

$$
y_{i j k l m}=\mu+S_{i}+L S_{j}+P_{k}+G_{l}+e_{i j k l m}
$$

(Equation 1)

where $y_{i j k l m}$ is the phenotypic value of litter size; $\mu$ is population mean; $S_{i}$ is the fixed effect of the $\mathrm{i}^{\text {th }}$ sire $(\mathrm{i}=1,2,3,4,5,6) ; L S_{j}$ is the fixed effect of the $\mathrm{j}^{\text {th }}$ kidding season $(\mathrm{j}=1,2,3,4) ; P_{k}$ is the fixed effect of the $\mathrm{k}^{\text {th }}$ parity $(\mathrm{k}=1,2,3) ; G_{l}$ is the fixed effect of the $1^{\text {th }}$ genotype $(1=1$, 
$2,3)$, and $e_{i j k l m}$ is random error effect of each observation. Analysis was performed using the general linear model procedure of SAS (Ver. 8.1) (SAS Institute Inc., Cary, NC, USA). Mean separation procedures were performed using a least significant difference test.

\section{RESULTS}

\section{Genetic polymorphism of the goat CART gene}

Genetic polymorphisms were detected in the whole CART gene including 3 exons and 2 introns. Based on SSCP and the sequence variations, the genotype and minor allele frequency were analyzed (Table 1). In exon 1, the mutation $77 \mathrm{~T} \rightarrow \mathrm{C}$ resulted in an amino acid change of Leu $\rightarrow$ Ser (Figure 1), where this variety was only found in Nanjiang huang and Matou goats. Another polymorphism point $126 \mathrm{C} \rightarrow \mathrm{T}$ did not alter the amino acid sequence. The other SNPs were found in introns, which were not in the coding region. Besides, three microsatellites were present in intron 2 of the CART gene, which were $939 \mathrm{C}_{7} \mathrm{~T}_{8} \rightarrow \mathrm{C}_{9} \mathrm{~T}_{8} / \mathrm{C}_{8} \mathrm{~T}_{8}$ (Figure 2), (CA $)_{7} \rightarrow(\mathrm{CA})_{10}$ (Figure 3), and $\mathrm{T}_{7} \rightarrow \mathrm{T}_{6}$. In terms of the $\chi^{2}$ test, analysis suggested that breeds of Guizhou white and Matou goats at mutation $196 \mathrm{C} \rightarrow \mathrm{A}, 524 \mathrm{C} \rightarrow \mathrm{T}$ as well as Nanjiang huang in locus 524 were not in Hardy-Weinberg equilibrium $(\mathrm{P}<0.01)$. Significant linkage disequilibrium was also detected in Chuandong white, Jintang black and Chengdu ma goats at $539 \mathrm{C} \rightarrow \mathrm{A}(\mathrm{P}<0.01)$. Moreover, in Jintang black and Chengdu ma goats, the microsatellite polymorphism $1216(\mathrm{~T})_{\mathrm{n}}$ and single nucleotide mutation $1229 \mathrm{G} \rightarrow$ A showed disequilibrium, $\mathrm{P}$ $<0.05$ and $\mathrm{P}<0.01$, respectively.

\section{Influence of fixed effects on litter size and birth weight in Chuandong white, Guizhou white, and Gulin ma goats}

Litter size and birth weight in Chuandong white, Guizhou white, and Gulin ma goats were significantly influenced by sire, kidding year and parity genotype $(\mathrm{P}<0.001, \mathrm{P}<0.05$ and $\mathrm{P}<0.05$, respectively). The least squares means and standard errors for litter size and birth weight of different CART genotypes in the three goat breeds are given in Table 2.

In the litter size trait, at position 524, different genotypes had no significant effect on the three breeds. However, for locus 539, goats with genotype CC had 0.28, 0.15 and 0.112 kids more than goats with genotype CA in Chuandong white, Guizhou white, and Gulin ma breeds, respectively. Meanwhile, goats with $\mathrm{C}_{n} \mathrm{~T}_{n} / \mathrm{C}_{n} \mathrm{~T}_{n}$ showed a significant difference in both Chuandong white and Guizhou white breeds $(\mathrm{P}<0.05)$. More specifically, goats with genotype $\mathrm{C}_{7} \mathrm{~T}_{8} / \mathrm{C}_{9} \mathrm{~T}_{8}$ yielded 0.28 more kids than those with $\mathrm{C}_{7} \mathrm{~T}_{8} / \mathrm{C}_{7} \mathrm{~T}_{8}$ and 0.20 more kids than those with $\mathrm{C}_{7} \mathrm{~T}_{8} / \mathrm{C}_{8} \mathrm{~T}_{8}$ in Chuandong white goats, respectively. Goats with genotype $\mathrm{C}_{7} \mathrm{~T}_{8} / \mathrm{C}_{9} \mathrm{~T}_{8}$ yielded 0.125 more kids than those with $\mathrm{C}_{7} \mathrm{~T}_{8} / \mathrm{C}_{7} \mathrm{~T}_{8}$ and 0.111 more kids than those with $\mathrm{C}_{7} \mathrm{~T}_{8} /$ $\mathrm{C}_{8} \mathrm{~T}_{8}$ in Guizhou white goats, respectively. Nevertheless, all the mutations analyzed in Table 2 showed no significant difference between the three breeds in the weight trait.

\section{DISCUSSION}

The hypothalamus is a key brain region involved in many peripheral signals and neuronal pathways that control energy homeostasis and food intake (Rocha et al., 2003; De Souza et al., 


\begin{tabular}{|c|c|c|c|c|c|c|c|c|c|c|c|c|}
\hline \multirow[t]{2}{*}{ Locus } & \multirow{2}{*}{\multicolumn{2}{|c|}{ Item }} & \multicolumn{10}{|c|}{ Breeds } \\
\hline & & & $\mathrm{CW}$ & JB & BJ & DB & $\mathrm{GW}$ & $\mathrm{NH}$ & $\mathrm{CM}$ & GM & Matou & Boer \\
\hline \multirow[t]{3}{*}{$77 \mathrm{~T} \rightarrow \mathrm{C}$} & Genotype & TT & 1.000 & 1.000 & 1.000 & 1.000 & 1.000 & 0.932 & 1.000 & 1.000 & 0.918 & 1.000 \\
\hline & & $\mathrm{TC}$ & 0 & 0 & 0 & 0 & 0 & 0.068 & 0 & 0 & 0.082 & 0 \\
\hline & Minor allele & $\mathrm{C}$ & 0 & 0 & 0 & 0 & 0 & 0.034 & 0 & 0 & 0.041 & 0 \\
\hline \multirow[t]{4}{*}{$126 \mathrm{C} \rightarrow \mathrm{T}$} & Genotype & $\mathrm{CC}$ & 0.907 & 0.875 & 1.000 & 1.000 & 1.000 & 0.878 & 0.974 & 1.000 & 1.000 & 1.000 \\
\hline & & $\mathrm{CT}$ & 0.093 & 0.125 & 0 & 0 & 0 & 0.108 & 0.026 & 0 & 0 & 0 \\
\hline & & TT & 0 & 0 & 0 & 0 & 0 & 0.014 & 0 & 0 & 0 & 0 \\
\hline & Minor allele & $\mathrm{T}$ & 0.047 & 0.062 & 0 & 0 & 0 & 0.064 & 0.013 & 0 & 0 & 0 \\
\hline \multirow[t]{4}{*}{$196 \mathrm{C} \rightarrow \mathrm{A}$} & Genotype & $\mathrm{CC}$ & 0.870 & 0.850 & 0.933 & 0.843 & 0.960 & 0.932 & 0.949 & 0.983 & 0.857 & 0.549 \\
\hline & & $\mathrm{CA}$ & 0.130 & 0.150 & 0.067 & 0.157 & 0.030 & 0.054 & 0.051 & 0.017 & 0.082 & 0.419 \\
\hline & & AA & 0 & 0 & 0 & 0 & 0.010 & 0.014 & 0 & 0 & 0.061 & 0.032 \\
\hline & Minor allele & $\mathrm{A}$ & 0.065 & 0.075 & 0.034 & 0.079 & 0.025 & 0.041 & 0.026 & 0.009 & 0.102 & 0.242 \\
\hline \multirow[t]{4}{*}{$524 \mathrm{C} \rightarrow \mathrm{T}$} & Genotype & $\mathrm{CC}$ & 0.833 & 0.800 & 1.000 & 0.765 & 0.970 & 0.986 & 0.923 & 0.897 & 0.919 & 1.000 \\
\hline & & $\mathrm{CT}$ & 0.167 & 0.175 & 0 & 0.235 & 0.020 & 0.014 & 0.077 & 0.103 & 0.061 & 0 \\
\hline & & $\mathrm{TT}$ & 0 & 0.025 & 0 & 0 & 0.010 & 0 & 0 & 0 & 0.020 & 0 \\
\hline & Minor allele & $\mathrm{T}$ & 0.084 & 0.088 & 0 & 0.118 & 0.020 & 0.007 & 0.039 & 0.052 & 0.051 & 0 \\
\hline \multirow[t]{4}{*}{$539 \mathrm{C} \rightarrow \mathrm{A}$} & Genotype & $\mathrm{CC}$ & 0.907 & 0.525 & 0.867 & 0.941 & 0.889 & 0.622 & 0.923 & 0.828 & 0.714 & 1.000 \\
\hline & & $\mathrm{CA}$ & 0.074 & 0.475 & 0.133 & 0.059 & 0.101 & 0.351 & 0.051 & 0.172 & 0.245 & 0 \\
\hline & & AA & 0.019 & 0 & 0 & 0 & 0.010 & 0.027 & 0.026 & 0 & 0.041 & 0 \\
\hline & Minor allele & $\mathrm{A}$ & 0.056 & 0.238 & 0.067 & 0.030 & 0.061 & 0.203 & 0.042 & 0.086 & 0.164 & 0 \\
\hline \multirow[t]{4}{*}{$695 \mathrm{C} \rightarrow \mathrm{G}$} & Genotype & $\mathrm{CC}$ & 1.000 & 1.000 & 1.000 & 0.980 & 0.990 & 0.986 & 1.000 & 0.966 & 0.980 & 0.355 \\
\hline & & CG & 0 & 0 & 0 & 0.020 & 0.010 & 0.014 & 0 & 0.034 & 0.020 & 0.516 \\
\hline & & GG & 0 & 0 & 0 & 0 & 0 & 0 & 0 & 0 & 0 & 0.129 \\
\hline & Minor allele & G & 0 & 0 & 0 & 0.010 & 0.005 & 0.007 & 0 & 0.017 & 0.010 & 0.387 \\
\hline $707 \mathrm{C} \rightarrow \mathrm{T}$ & Genotype & $\mathrm{CC}$ & 1.000 & 1.000 & 1.000 & 0.980 & 0.990 & 0.986 & 1.000 & 0.966 & 0.980 & 0.355 \\
\hline $725 \mathrm{C} \rightarrow \mathrm{T}$ & & $\mathrm{CT}$ & 0 & 0 & 0 & 0.020 & 0.010 & 0.014 & 0 & 0.034 & 0.020 & 0.516 \\
\hline \multirow{2}{*}{$764 \mathrm{C} \rightarrow \mathrm{T}$} & & $\mathrm{TT}$ & 0 & 0 & 0 & 0 & 0 & 0 & 0 & 0 & 0 & 0.129 \\
\hline & Minor allele & $\mathrm{T}$ & 0 & 0 & 0 & 0.010 & 0.005 & 0.007 & 0 & 0.017 & 0.010 & 0.387 \\
\hline \multirow[t]{6}{*}{939 CT repeats } & Genotype & $\mathrm{C}_{7} \mathrm{~T}_{8} / \mathrm{C}_{7} \mathrm{~T}_{8}$ & 0.722 & 0.525 & 0.622 & 1.000 & 0.798 & 0.676 & 0.923 & 0.741 & 0.612 & 0.387 \\
\hline & & $\mathrm{C}_{7} \mathrm{~T}_{8} / \mathrm{C}_{9} \mathrm{~T}_{8}^{8}$ & 0.056 & 0.150 & 0.222 & 0 & 0.040 & 0.176 & 0.026 & 0.120 & 0.122 & 0.258 \\
\hline & & $\mathrm{C}_{9} \mathrm{~T}_{8}^{8} / \mathrm{C}_{9} \mathrm{~T}_{8}^{8}$ & 0.037 & 0 & 0.022 & 0 & 0.010 & 0 & 0.026 & 0.017 & 0.020 & 0.161 \\
\hline & & $\mathrm{C}_{7} \mathrm{~T}_{8}^{8} / \mathrm{C}_{8} \mathrm{~T}_{8}^{8}$ & 0.185 & 0.300 & 0.133 & 0 & 0.151 & 0.149 & 0.026 & 0.120 & 0.245 & 0.194 \\
\hline & Minor allele & $\mathrm{C}_{9} \mathrm{~T}_{7}^{8}$ & 0.065 & 0.075 & 0.133 & 0 & 0.030 & 0.088 & 0.039 & 0.077 & 0.081 & 0.290 \\
\hline & & $\mathrm{C}_{8}^{9} \mathrm{~T}_{7}$ & 0.093 & 0.150 & 0.067 & 0 & 0.076 & 0.075 & 0.013 & 0.060 & 0.123 & 0.097 \\
\hline \multirow[t]{3}{*}{$1108(\mathrm{CA})$ repeats } & Genotype & $(\mathrm{CA})_{7} /(\mathrm{CA})_{7}$ & 1.000 & 1.000 & 1.000 & 1.000 & 1.000 & 1.000 & 1.000 & 1.000 & 1.000 & 0.898 \\
\hline & & $(\mathrm{CA})_{7} /(\mathrm{CA})_{10}$ & 0 & 0 & 0 & 0 & 0 & 0 & 0 & 0 & 0 & 0.102 \\
\hline & Minor allele & $(\mathrm{CA})_{10}$ & 0 & 0 & 0 & 0 & 0 & 0 & 0 & 0 & 0 & 0.061 \\
\hline \multirow[t]{4}{*}{$1216 \mathrm{~T}$ repeats } & Genotype & $\mathrm{T}_{7} \mathrm{~T}_{7}$ & 1.000 & 0.600 & 0.889 & 0.922 & 0.922 & 0.662 & 0.897 & 0.810 & 0.673 & 0.903 \\
\hline & & $\mathrm{T}_{7} \mathrm{~T}_{6}$ & 0 & 0.400 & 0.111 & 0.078 & 0.071 & 0.297 & 0.077 & 0.190 & 0.286 & 0.097 \\
\hline & & $\mathrm{T}_{6} \mathrm{~T}_{6}^{0}$ & 0 & 0 & 0 & 0 & 0 & 0.041 & 0.026 & 0 & 0.041 & 0 \\
\hline & Minor allele & $\mathrm{T}_{6} 6$ & 0 & 0.200 & 0.056 & 0.039 & 0.036 & 0.190 & 0.065 & 0.095 & 0.184 & 0.049 \\
\hline \multirow[t]{4}{*}{$1229 \mathrm{G} \rightarrow \mathrm{A}$} & Genotype & GG & 1.000 & 0.600 & 0.889 & 0.922 & 0.922 & 0.662 & 0.897 & 0.810 & 0.673 & 0.903 \\
\hline & & GA & 0 & 0.400 & 0.111 & 0.078 & 0.071 & 0.297 & 0.077 & 0.190 & 0.286 & 0.097 \\
\hline & & AA & 0 & 0 & 0 & 0 & 0 & 0.041 & 0.026 & 0 & 0.041 & 0 \\
\hline & Minor allele & A & 0 & 0.200 & 0.056 & 0.039 & 0.036 & 0.190 & 0.065 & 0.095 & 0.184 & 0.049 \\
\hline
\end{tabular}

Exons 1, 2 and 3 are located at base pairs 1-146, 586-669, and 1507-1599. $\mathrm{CW}=$ Chuandong white $(\mathrm{N}=55) ; \mathrm{JB}=$ Jintang black $(\mathrm{N}=41)$; $\mathrm{BJ}=$ Banjiao $(\mathrm{N}=45)$; $\mathrm{DB}=$ Dazu black $(\mathrm{N}=51)$; $\mathrm{GW}=$ Guizhou white $(\mathrm{N}=99)$; $\mathrm{NH}=$ Nanjiang huang $(\mathrm{N}=74)$; $\mathrm{CM}=$ Chengdu ma $(\mathrm{N}=40)$; $\mathrm{GM}=\operatorname{Gulin}$ ma $(\mathrm{N}=58)$; Matou $(\mathrm{N}=49)$; $\operatorname{Boer}(\mathrm{N}=31)$.

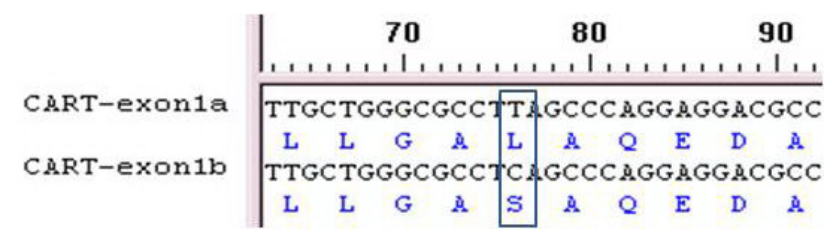

Figure 1. Nucleotide sequence and amino acid sequence blasted by DNAMAN between different genotypes in exon 1 of the CART gene. 

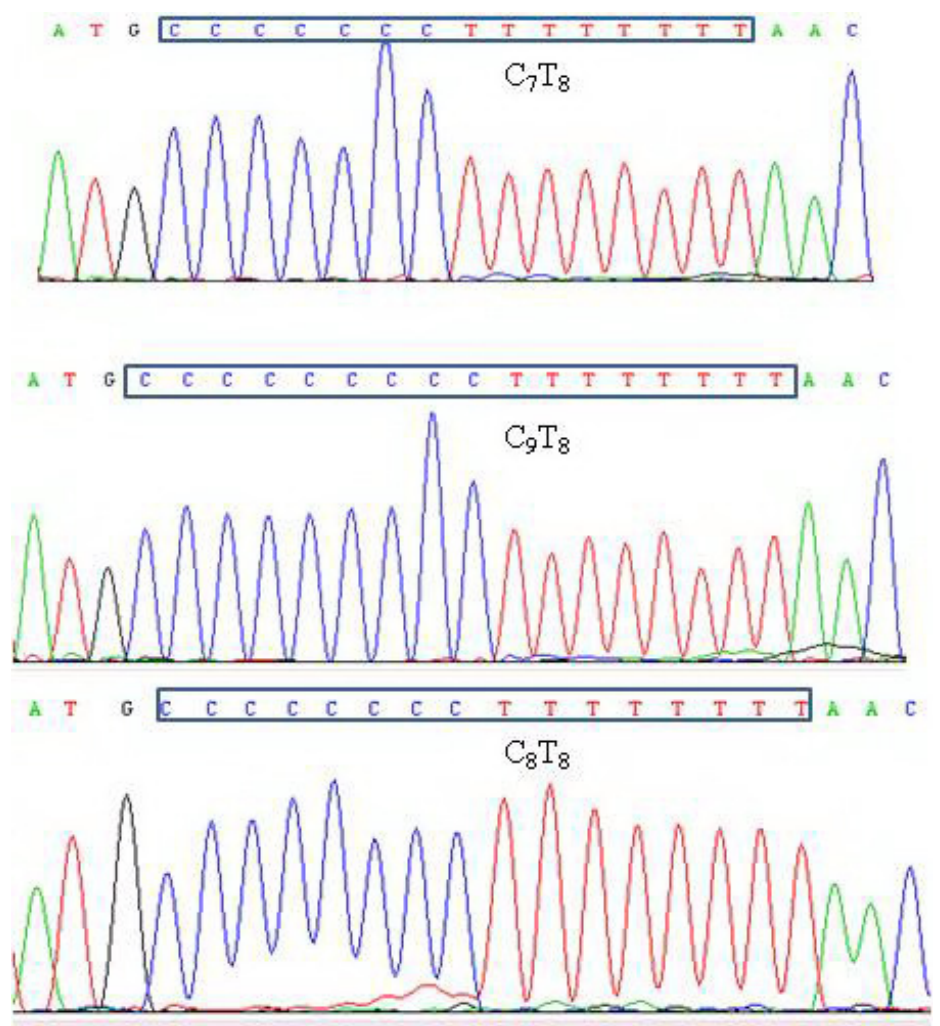

Figure 2. Nucleotide mutations between different genotypes at position 939 of the CART gene.

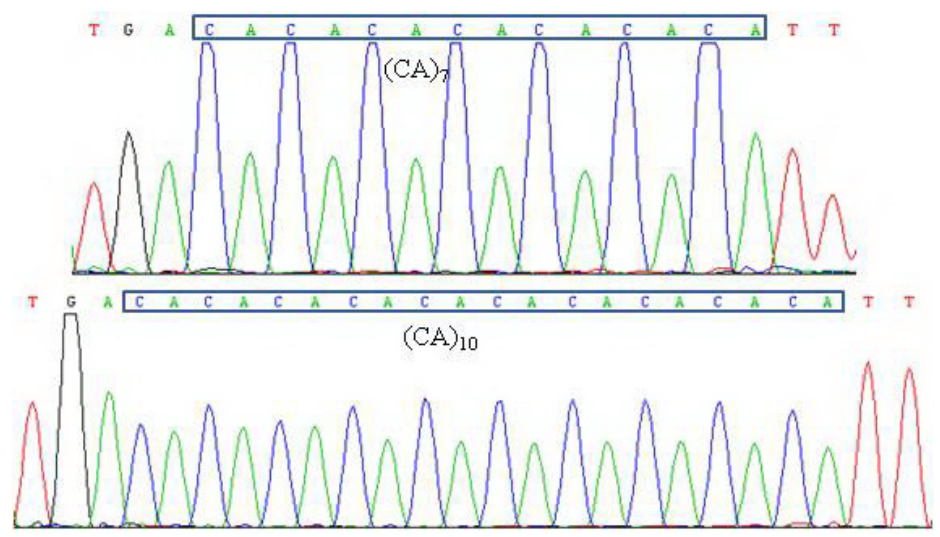

Figure 3. Nucleotide mutations between different genotypes at position 1108 of the CART gene.

2007; Hill et al., 2008). The sensitivity of the reproductive axis to energy availability has been recently highlighted in the increase in food intake, which in turn, produces a positive energy balance to meet the metabolic demands associated with the challenge of reproduction (Rocha et al., 2003). As a matter of fact, the importance of CART in the hypothalamic-pituitary-gonadal axis as well as in the hypothalamic-pituitary-adrenal axis, particularly in the regulation of GnRH secretion and 


\begin{tabular}{|c|c|c|c|c|c|c|c|}
\hline \multirow[t]{2}{*}{ Locus } & \multirow[t]{2}{*}{ Genotypes } & \multicolumn{2}{|c|}{ Chuandong white } & \multicolumn{2}{|c|}{ Guizhou white } & \multicolumn{2}{|c|}{ Gulin ma } \\
\hline & & $\begin{array}{c}\text { Litter size } \\
(\mu \pm \mathrm{SE})\end{array}$ & $\begin{array}{l}\text { Birth weight } \\
(\mathrm{kg})(\mu \pm \mathrm{SE})\end{array}$ & $\begin{array}{l}\text { Litter size } \\
(\mu \pm \mathrm{SE})\end{array}$ & $\begin{array}{l}\text { Birth weight } \\
(\mathrm{kg})(\mu \pm \mathrm{SE})\end{array}$ & $\begin{array}{l}\text { Litter size } \\
(\mu \pm \mathrm{SE})\end{array}$ & $\begin{array}{l}\text { Birth weight } \\
(\mathrm{kg})(\mu \pm \mathrm{SE})\end{array}$ \\
\hline \multirow[t]{2}{*}{$524 \mathrm{C} \rightarrow \mathrm{T}$} & $\mathrm{CC}$ & $1.74^{\mathrm{a}} \pm 0.04$ & $2.49^{\mathrm{a}} \pm 0.07$ & $1.558^{\mathrm{a}} \pm 0.04$ & $1.92^{\mathrm{a}} \pm 0.05$ & $1.698^{\mathrm{a}} \pm 0.03$ & $2.29^{\mathrm{a}} \pm 0.05$ \\
\hline & $\mathrm{CT}$ & $1.78^{\mathrm{a}} \pm 0.11$ & $2.45^{\mathrm{a}} \pm 0.19$ & - & - & $1.667^{\mathrm{a}} \pm 0.15$ & $2.34^{\mathrm{a}} \pm 0.15$ \\
\hline \multirow[t]{2}{*}{$539 \mathrm{C} \rightarrow \mathrm{A}$} & $\mathrm{CC}$ & $1.72^{\mathrm{a}} \pm 0.03$ & $2.51^{\mathrm{a}} \pm 0.05$ & $1.540^{\mathrm{a}} \pm 0.05$ & $1.94^{\mathrm{a}} \pm 0.07$ & $1.688^{\mathrm{a}} \pm 0.04$ & $2.32^{\mathrm{a}} \pm 0.07$ \\
\hline & $\mathrm{CA}$ & $2.00^{\mathrm{b}} \pm 0.14$ & $2.42^{\mathrm{a}} \pm 0.22$ & $1.690^{\mathrm{b}} \pm 0.12$ & $1.88^{\mathrm{a}} \pm 0.27$ & $1.800^{\mathrm{b}} \pm 0.12$ & $2.26^{\mathrm{a}} \pm 0.11$ \\
\hline \multirow[t]{3}{*}{939 CT repeats } & $\mathrm{C}_{7} \mathrm{~T}_{8} / \mathrm{C}_{7} \mathrm{~T}_{8}$ & $1.72^{\mathrm{a}} \pm 0.04$ & $2.52^{\mathrm{a}} \pm 0.06$ & $1.542^{\mathrm{a}} \pm 0.05$ & $1.93^{\mathrm{a}} \pm 0.08$ & $1.693^{\mathrm{a}} \pm 0.04$ & $2.31^{\mathrm{a}} \pm 0.07$ \\
\hline & $\mathrm{C}_{7} \mathrm{~T}_{8}^{8} / \mathrm{C}_{9} \mathrm{~T}_{8}^{8}$ & $2.00^{\mathrm{b}} \pm 0.15$ & $2.42^{\mathrm{a}} \pm 0.25$ & $1.667^{\mathrm{b}} \pm 0.16$ & $1.87^{\mathrm{a}} \pm 0.29$ & $1.714^{\mathrm{a}} \pm 0.17$ & $2.24^{\mathrm{a}} \pm 0.13$ \\
\hline & $\mathrm{C}_{7} \mathrm{~T}_{8} / \mathrm{C}_{8} \mathrm{~T}_{8}^{8}$ & $1.80^{\mathrm{a}} \pm 0.10$ & $2.48^{\mathrm{a}} \pm 0.12$ & $1.556^{\mathrm{a}} \pm 0.12$ & $1.90^{\mathrm{a}} \pm 0.20$ & $1.714^{\mathrm{a}} \pm 0.18$ & $2.26^{\mathrm{a}} \pm 0.14$ \\
\hline
\end{tabular}

Least square mean values with different superscript letters in the same row are significantly different $(\mathrm{P}<0.05)$.

controversially the onset of puberty, has been reported (Boone et al., 2008). Obviously, the CART gene could be a candidate gene in reproduction.

In this study, 10 nucleotide mutations and 3 microsatellites were detected, the first two SNPs $(77 \mathrm{~T} \rightarrow \mathrm{C}, 126 \mathrm{C} \rightarrow \mathrm{T})$ were located in exon 1 of the $\mathrm{CART}$ gene, and the others were located in the introns. All the SNPs found in goats are novel. With regard to the microsatellites, the (CA) repeat is consistent with the study by Valle et al. (2005) in cattle. Great diversity in different breeds with the same mutation was also found in these traits; take $1229 \mathrm{G} \rightarrow \mathrm{A}$ for example, where the frequencies of the minor allele ranged from 0 to 0.200 in 10 breeds. This may indicate that some SNPs are special for some indigenous populations. With respect to the litter size trait, polymorphisms of $\mathrm{C}_{\mathrm{n}} \mathrm{T}_{\mathrm{n}}$ showed a significant difference in both Chuandong white and Guizhou white goats, and $539 \mathrm{C} \rightarrow$ A displayed a significant difference in the three breeds. Evidently, however, those mutations have no impact on birth weight; this result is consistent with the questions previously raised by Rogge et al. (2008) that not all findings obviously support the idea that CART peptides affect body weight. Nonetheless, associations between genetic polymorphisms and reproduction traits in goat are an important step in understanding the genetics of complex traits that are commercially important. Although the results of this study suggest that several genetic varieties in this gene affect litter size, the mechanisms of these genetic changes remain unclear, because most of them do not cause amino acid changes. It is possible that they affect the transcription of the genes, splicing, or even translation. As more knowledge is available on how noncoding sequences affect gene function, it may become apparent how these SNPs contribute to variation in these traits. Overall, this was a preliminary study that explored the genetic polymorphism of the CART gene, and indicated that some SNPs may play an important role in the regulation of reproduction. The genetic mechanism of reproduction in goat breeds should be further investigated.

\section{ACKNOWLEDGMENTS}

Research supported by the Earmarked Fund for China Agriculture Research System (\#CARS-39) and Natural Science Foundation Project of CQ CSTC (\#2009BA1066).

\section{REFERENCE}

Boone EM, Hawks BW, Li W and Garlow SJ (2008). Genetic regulation of hypothalamic cocaine and amphetamineregulated transcript (CART) in BxD inbred mice. Brain Res. 1194: 1-7. 
De Souza MJ, Lee DK, VanHeest JL, Scheid JL, et al. (2007). Severity of energy-related menstrual disturbances increases in proportion to indices of energy conservation in exercising women. Fertil. Steril. 88: 971-975.

Derks NM, Gaszner B, Bernhardt K, Roubos EW, et al. (2009). Sex-specific expression of BDNF and CART in the midbrain non-preganglionic Edinger-Westphal nucleus in the rat. Peptides 30: 2268-2274.

Douglass J, McKinzie AA and Couceyro P (1995). PCR differential display identifies a rat brain mRNA that is transcriptionally regulated by cocaine and amphetamine. J. Neurosci. 15: 2471-2481.

Fekete C and Lechan RM (2006). Neuroendocrine implications for the association between cocaine- and amphetamineregulated transcript (CART) and hypophysiotropic thyrotropin-releasing hormone (TRH). Peptides 27: 2012-2018.

Fekete C, Mihaly E, Luo LG, Kelly J, et al. (2000). Association of cocaine- and amphetamine-regulated transcriptimmunoreactive elements with thyrotropin-releasing hormone-synthesizing neurons in the hypothalamic paraventricular nucleus and its role in the regulation of the hypothalamic-pituitary-thyroid axis during fasting. $J$. Neurosci. 20: 9224-9234.

Hill JW, Elmquist JK and Elias CF (2008). Hypothalamic pathways linking energy balance and reproduction. Am. J. Physiol. Endocrinol. Metab. 294: E827-E832.

Kalra SP, Dube MG, Pu S, Xu B, et al. (1999). Interacting appetite-regulating pathways in the hypothalamic regulation of body weight. Endocr. Rev. 20: 68-100.

Koylu EO, Couceyro PR, Lambert PD and Kuhar MJ (1998). Cocaine- and amphetamine-regulated transcript peptide immunohistochemical localization in the rat brain. J. Comp. Neurol. 391: 115-132.

Lima FB, Henderson JA, Reddy AP, Tokuyama Y, et al. (2008). Unique responses of midbrain CART neurons in macaques to ovarian steroids. Brain Res. 1227: 76-88.

Rocha M, Bing C, Williams G and Puerta M (2003). Pregnancy-induced hyperphagia is associated with increased gene expression of hypothalamic agouti-related peptide in rats. Regul. Pept. 114: 159-165.

Rogge G, Jones D, Hubert GW, Lin Y, et al. (2008). CART peptides: regulators of body weight, reward and other functions. Nat. Rev. Neurosci. 9: 747-758.

Smith SM, Vaughan JM, Donaldson CJ, Rivier J, et al. (2004). Cocaine- and amphetamine-regulated transcript activates the hypothalamic-pituitary-adrenal axis through a corticotropin-releasing factor receptor-dependent mechanism. Endocrinology 145: 5202-5209.

Stachowiak M, Cieslak J, Skorczyk A, Nowakowska J, et al. (2009). The pig CART (cocaine- and amphetamine-regulated transcript) gene and association of its microsatellite polymorphism with production traits. J. Anim. Breed. Genet. 126: $37-42$.

Valle E, Moore SS, Jann O, Williams JL, et al. (2005). The bovine cocaine and amphetamine-regulated transcript locus: gene characterization and SNP discovery. Anim. Genet. 36: 74-75.

Van Vugt DA, Lujan ME, Froats M, Krzemien A, et al. (2006). Effect of fasting on cocaine-amphetamineregulated transcript, neuropeptide $\mathrm{Y}$, and leptin receptor expression in the non-human primate hypothalamus. Neuroendocrinology 84: 83-93.

Yanik T, Dominguez G, Kuhar MJ, Del Giudice EM, et al. (2006). The Leu34Phe ProCART mutation leads to cocaineand amphetamine-regulated transcript (CART) deficiency: a possible cause for obesity in humans. Endocrinology 147: 39-43.

Zhang CL, Chen H, Wang YH, Lan XY, et al. (2008). The polymorphisms of bovine cocaine- and amphetamine-regulated transcripts and their associations with cattle (Bos taurus) growth traits. J. Biosci. 33: 365-370. 